\title{
Assessing the Impact of Traffic Emissions on Fine Particulate Matter and Carbon Monoxide Levels in
}

Aerosol and Air Quality Research

Special Issue:

Special Issue on COVID-19 Aerosol Drivers, Impacts and Mitigation (XVIII)

\section{OPEN ACCESS}

Received: April 11, 2021

Revised: July 5, 2021

Accepted: July 25, 2021

${ }^{*}$ Corresponding Author: thuy.lybich@hust.edu.vn

\section{Publisher:}

Taiwan Association for Aerosol Research

ISSN: $1680-8584$ print ISSN: 2071-1409 online

cc) Copyright: The Author(s). This is an open access article distributed under the terms of the Creative Commons Attribution License (CC BY 4.0), which permits unrestricted use, distribution, and reproduction in any medium, provided the original author and source are cited.

\author{
Nhung H. Le', Bich-Thuy Ly ${ }^{2 *}$, Phong K. Thai ${ }^{3}$, Gia-Huy Pham ${ }^{4}$, \\ Ich-Hung $\mathrm{Ngo}^{2}$, Van-Nguyet $\mathrm{Do}^{1}$, Thuy T. Le ${ }^{5}$, Luan V. Nhu ${ }^{6}$, \\ Ha Dang Son ${ }^{7}$, Yen-Lien T. Nguyen ${ }^{8}$, Duong H. Pham ${ }^{5}$, Tuan V. Vu ${ }^{9}$
}

${ }^{1}$ Live \& Learn for Environment and Community, Hanoi, Vietnam

${ }^{2}$ School of Environmental Science and Technology, Hanoi University of Science and Technology, Hanoi, Vietnam

${ }^{3}$ Queensland Alliance for Environmental Health Sciences (QAEHS), The University of Queensland, 4102 QLD, Australia

${ }^{4}$ Graduate School of Global Environmental Studies, Kyoto University, Kyoto 606-8501, Japan

${ }^{5}$ Hanoi Environmental Protection Agency, Department of Natural Resources and Environment, Hanoi, Vietnam

${ }^{6}$ Ministry of Natural Resources and Environment, Northern Center for Environmental Monitoring, Hanoi, Vietnam

${ }^{7}$ Centre for Energy and Green Growth Research, Hanoi, Vietnam

${ }^{8}$ Faculty of Transport Safety and Environment, University of Transport and Communications, Hanoi, Vietnam

${ }^{9}$ Environmental Research Group, School of Public Health, Imperial College London, London W12 OBZ, UK

\section{ABSTRACT}

Hanoi, Vietnam, is usually ranked as one of the most polluted capital cities in terms of air quality, particularly $\mathrm{PM}_{2.5}$. However, there has not been enough data to determine the main source of this pollution. In this study, we utilized the rare opportunity of the COVID-19 social distancing to assess the contribution of traffic emission to $\mathrm{PM}_{2.5}$ and $\mathrm{CO}$ levels when traffic volume was reduced significantly in Hanoi. Hourly $\mathrm{PM}_{2.5}$ and $\mathrm{CO}$ concentrations were measured from nine urban and traffic monitoring stations during pre-, soft, hard, and post-social distancing periods. As a result, we observed large reductions in both $\mathrm{PM}_{2.5}$ and $\mathrm{CO}$ levels during social distancing periods. $\mathrm{PM}_{2.5}$ concentrations were $14-18 \%$ lower during the social distancing than before this period, while CO concentrations had a more considerable drop by $28-41 \%$. It is known that meteorological conditions can have significant effects on the ambient levels of air pollutants. To overcome this challenge, weather normalized concentrations of those pollutants were estimated using the random forest model, a machine learning technique. The normalized weather concentrations showed smaller reductions by $7-10 \%$ for $\mathrm{PM}_{2.5}$ and $5-11 \%$ for $\mathrm{CO}$, indicating the presence of favorable weather conditions for better air quality during the social distancing period. In further analysis, the apparent improvement of air quality in Hanoi during the social distancing period was in line with reducing traffic emissions while emissions from coal-fired power plants remained relatively stable.

Keywords: COVID-19, Air quality, Hanoi, Southeast Asia, Weather normalization

\section{INTRODUCTION}

The severity of the COVID-19 outbreak has urged governments to take strong measures to 
protect public health and stem the transmission of the virus (Abdullah et al., 2020). As one of the most effective measures, lockdown/social distancing has been enforced in various countries to reduce human contact and reduce contagion. The restriction on the movement of the population and sometimes industrial activities would subsequently affect air quality.

The influences of the lockdown/social distancing on air pollution have been studied around the world (Chauhan and Singh, 2020; Dantas et al., 2020; Jain and Sharma, 2020; Otmani et al., 2020; Tobías et al., 2020; Xu et al., 2020; Zhu et al., 2020). PM2.5 concentrations from stations in major cities (New York, Los Angeles, Zaragoza, Rome, Dubai, Delhi, Mumbai, Beijing, and Shanghai) that suffered from COVID-19 severity declined (Chauhan and Sighn, 2020). $\mathrm{NO}_{2}$ concentrations observed by satellites in Europe and Asia also apparently reduced due to COVID-19 lockdown (Agency, 2020; Patel and Stevens, 2020). Various reductions in CO concentrations have been reported in different Asian urban areas during the lockdown period in 2020, e.g., $22.7 \%$ in WuhanChina (Lian et al., 2020), 16\% in Bangalore, 25\% in Chennai, 29\% in Kolkata, and Delhi, $46 \%$ in Mumbai-India, (Jain and Sharma, 2020) or 1-27\% in many towns of Malaysia (Suhaimi et al., 2020). Besides the decreasing trends, there were occasions where such trends were either unclear or reversed. In such cases, proposed explanations included increasing local burning activities (Nadzir et al., 2020) and unfavorable meteorological conditions, or both (Wang et al., 2020).

Weather conditions are well-known as key factors affecting air quality levels due to their strong impacts on both physical and chemical processes such as dispersion, deposition, and evaporation of air pollutants in the atmosphere. Therefore, to assess the changes in air quality, the methods should account for meteorological effects. Accordingly, Carslaw (2009) first introduced the method called weather normalization in 2009 using boosted regression tree. It was then modified by Grange et al. (2018) using a random forest algorithm. In this study, we applied the method from Grange's work with a modification by Vu et al. (2019). In this method, the random forest (RF) model, a machine learning technique, randomly generate new sets of input data (including time variables (except for Epoch time) and meteorological parameters) and then fed into the previously developed RF algorithm to predict pollutant concentrations at a target hour. This step is repeated thousands of times to aggregate the final predicted pollutant concentration (the normalized weather concentration). The RF model constructs the relationship of air pollutant concentrations and meteorological conditions, which has several advantages in predicting air pollutant concentration and has been applied in evaluating the trend of air quality in different areas (Grange et al., 2018; Vu et al., 2019) or determining the effect of COVID-19 social lockdown on air quality (Shi et al., 2021).

Vietnam recorded its first positive COVID-19 case in late January 2020. Due to the rapid spread of the virus, on 30 March, the Vietnamese Government signed a directive implementing the hard social distancing policy from 1 to 15 April 2020 and subsequently extending a further seven days in 12 provinces, including Hanoi (Nhu, 2020). During the hard social distancing period, traffic density reduced as schools, universities were closed, and citizens were encouraged to practice social distancing by staying home and avoiding crowded places (Ha et al., 2020). By 23 April, Hanoi eased the social distancing and resumed most of the activities, including transportation except schools, which gradually enhanced residential mobilities (Anh,2020). This social distancing period presented an opportunity for a natural experiment to evaluate the impact of human activities on Hanoi air quality. We hypothesized that transportation is the main emission source for air pollutants in Hanoi (Cohen et al., 2010; Ly et al., 2020; Sakamoto et al., 2018; Truc and Kim Oanh, 2007). The reduction in population mobility could lead to an improvement in air quality. Because of the insufficient input data and validation measurement for complex modeling in Vietnam, which may be similar to other developing countries, using statistical modeling and this rare natural experiment can create useful results to better understand air pollution and support policy formation.

The study investigated variations of $\mathrm{PM}_{2.5}$ and $\mathrm{CO}$ in Hanoi in the pre-, during, and post-social distancing periods with considerations of the impacts of meteorological parameters and longrange transport. Those effects were assessed using the weather normalization approach, which normalizes meteorological and long-range transport factors through a thousand RF prediction times. Besides, the variations of emission strength of transportation and coal power plants are under discussion to obtain insights into the potential influences of those emission sources on Hanoi's air quality. 


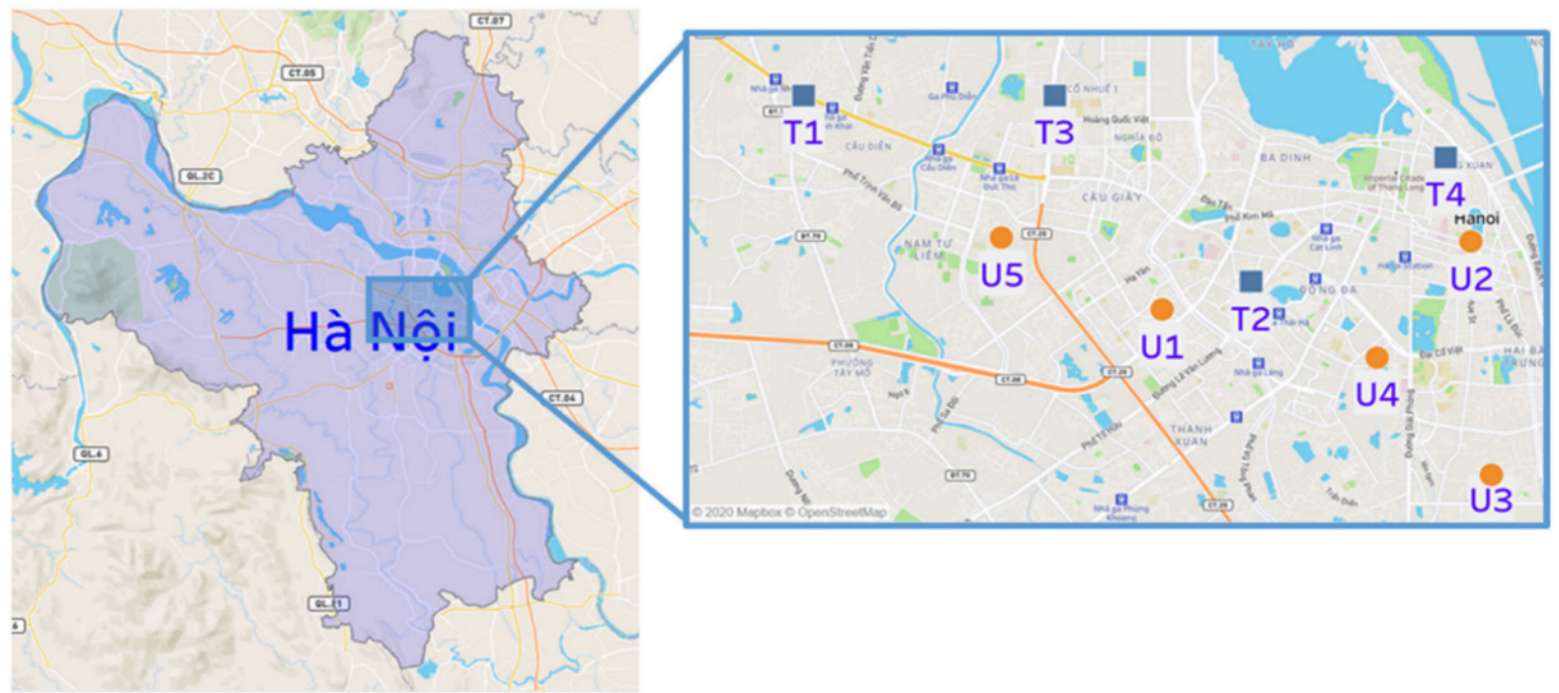

Fig. 1. Map of nine monitoring stations included in this study.

\section{METHODS}

\subsection{Monitoring Sites, Instruments, and Monitoring Data}

Hourly concentrations of $\mathrm{PM}_{2.5}$ and $\mathrm{CO}$ from nine monitoring stations operating by the Hanoi Natural Resources \& Environment Department (Hanoi DONRE) were obtained in this study. Fig. 1 and Table S1 presented the location and characteristics of the selected stations categorized as urban (U) and traffic $(T)$. The measurement instruments in those sites were divided into two groups: standard instruments equipped for the U-1 and T-1 stations and sensors for the other stations. The U-1 and T-1 use the beta attenuation monitors for $\mathrm{PM}_{2.5}$ (U.S.-EPA Automated Equivalent Method - MP101M, Environment S.A (ENVEA)) and non-dispersive infrared spectrometry method for CO (US-EPA Automated Reference Method - CO12M, ENVEA) (Hanoi, DONRE, 2018). Other stations use the optical scattering method for $\mathrm{PM}_{2.5}$ and the electrochemical method for CO (Cairsens ${ }^{\circledR}$ micro-sensors, ENVEA) (ENVEA, 2021). Those instruments are maintained and calibrated periodically by Hanoi DONRE.

The research acquired data from 1 March to 30 May 2020 to cover different periods; 1-21 March 2020 denoted as 'pre-social distancing period'; 22-31 March 2020 as 'soft social distancing period'; 1-22 April 2020 as 'hard social distancing period'; 23 April-31 May 2020 as 'post-social distancing period'.

\subsubsection{Additional data sources}

The source of meteorological parameters (wind speed/direction, temperature, pressure, and relative humidity) at Noibai airport were from NOAA Integrated Surface Database (12-melevation) via the "worldMet" R-package. Precipitation and radiation were obtained from nine Hanoi Natural Resources \& Environment Department monitoring stations.

Transportation data were obtained from the COVID-19 Community Mobility report by Google (Google, 2020) and the COVID-19 Mobility trend report by Apple (Apple, 2020).

Electricity production data were obtained from Vietnam National Energy Efficiency Programme (VNEEP), the National Load Dispatch Center (NLDC), and the Electricity Regulatory Authority of Vietnam (ERAV). Assessments of existing coal power plants were provided by courtesy of the United States Agency for International Development-Vietnam Low Emission Energy Program (USAID V-LEEP).

\subsection{Data Processing}

\subsubsection{Concentration weighted trajectory (CWT) approach}

In the concentration weighted trajectory (CWT) model, the concentration of air pollutant at 
each grid cell is estimated by the sum of pollutant concentration measured upon arrival of all air mass trajectories and weighted with the residential time of each trajectory and the total number of trajectories come to that grid cell. The heat map of CWT during a period shows the most potential source areas of long-range transports of that pollutant in that period. In this study, backward trajectories were computed based on wind data derived from twice-daily radiosonde balloon measurements (Stein et al., 2015) with the HYSPLIT4 model using NCEP/NCAR reanalysis gridded meteorological data (set-up back time: $-96 \mathrm{~h}$ with a receiving height of $120 \mathrm{~m}$ ). Air trajectory to Hanoi every hour was applied. The analysis was done based on the "openair" R-package.

\subsubsection{Random forest (RF) model and weather normalization of $\mathrm{PM}_{2.5}$ and $\mathrm{CO}$ concentrations}

In addition to sources, other factors were demonstrated to contribute to the variations of $\mathrm{PM}_{2.5}$ concentrations in Hanoi. Those factors are meteorological conditions, long-range transport of air masses, and secondary particle formation (Cohen et al., 2010; Hai and Kim Oanh, 2013; Hien et al., 2002; Hien et al., 2011; Kim Oanh et al., 2006; Ly et al., 2019).

The RF model was applied to describe the relationship between hourly pollutant concentrations $\left(\mathrm{PM}_{2.5}, \mathrm{CO}\right)$ and the predictor variables as regression decision trees (Vu et al., 2019). These predictor variables included temporal variables (Unix Epoch time (t trend), hour (0-23), weekday (MondaySunday), meteorological parameters (wind speed, wind direction, pressure, precipitation, temperature, relative humidity, and radiation), and air mass trajectory clusters. The effect of longrange transport was considered by inputting the air mass trajectory clusters in the model. However, those clusters demonstrated categorical information rather than a quantitative measurement of air mass trajectory.

In this study, a training data set ( $80 \%$ of total available data, which was randomly selected) constructed for the RF model, and then an unseen data set ( $20 \%$ left of all data points) would validate predicted results. Air mass trajectory clusters were determined by the HYSPLIT model using similar conditions as in the CWT model. The method to construct RF and calculate normalized weather concentrations is similar to the method used in Vu et al. (2019). Generally, the weather normalizing method also includes the impact of both seasonal and weather variations. In the method used in Vu et al. (2019), to improve the algorithm, meteorological variables of only the same hour in other days within two weeks before and after the investigated hour were selected (Vu et al., 2019).

\section{RESULTS AND DISCUSSION}

\section{1 $\mathrm{PM}_{2.5}$ and $\mathrm{CO}$ Concentrations during Studied Periods in $\mathbf{2 0 2 0}$}

\subsubsection{PM2.5 concentrations}

Fig. 2(a) illustrates the daily mean $\mathrm{PM}_{2.5}$ concentrations in urban and traffic areas. During the study period, daily $\mathrm{PM}_{2.5}$ concentrations ranged widely from 10 to $130 \mu \mathrm{g} \mathrm{m}^{-3}$. The concentrations of $\mathrm{PM}_{2.5}$ recorded in 2020 varied in the same range as in 2019. The detailed statistics and confidential intervals (Cl) in 2019 and 2020 by each period are provided in Table S2. In 2020, $\mathrm{PM}_{2.5}$ concentrations were $48(95 \% \mathrm{Cl}: 45.7,50.5)$ and $62(95 \% \mathrm{Cl}: 59.3,65) \mu \mathrm{g} \mathrm{m}^{-3}$ for urban and traffic sites in the pre-social distancing period. During soft and hard social distancing periods of 2020, $\mathrm{PM}_{2.5}$ concentrations declined by $18 \%$ and $13 \%$ in urban sites and by $15 \%$ and $14 \%$ in traffic sites in soft- and hard- distancing periods. The concentration declined further by $29 \%$ and $30 \%$ in the post-social distancing period, at urban and traffic sites, respectively. Because pollutant concentrations can be affected by meteorological conditions, discussion about trends without meteorological effects is presented in Section 3.3.1.

Fig. S1 (Supplementary Material) presents the correlation coefficients ( $r$ ) of $\mathrm{PM}_{2.5}$ concentrations at nine stations in the studied periods are. High correlation, $r>0.80$ for all sites, demonstrated the strong effects of regional sources on $\mathrm{PM}_{2.5}$ levels. No clear traffic rush-hour peaks were observed for $\mathrm{PM}_{2.5}$ even at roadside sites. However, the $\mathrm{PM}_{2.5}$ levels at traffic sites were consistently higher than in urban sites in 2020 during pre-, soft, hard, and post-social distancing periods, respectively (at 14.2, 13.3, 11.6, and $9.6 \mu \mathrm{g} \mathrm{m}^{-3}$ ) (Fig. 2(b)). This fact indicated an influence of traffic on $\mathrm{PM}_{2.5}$ 
(a)

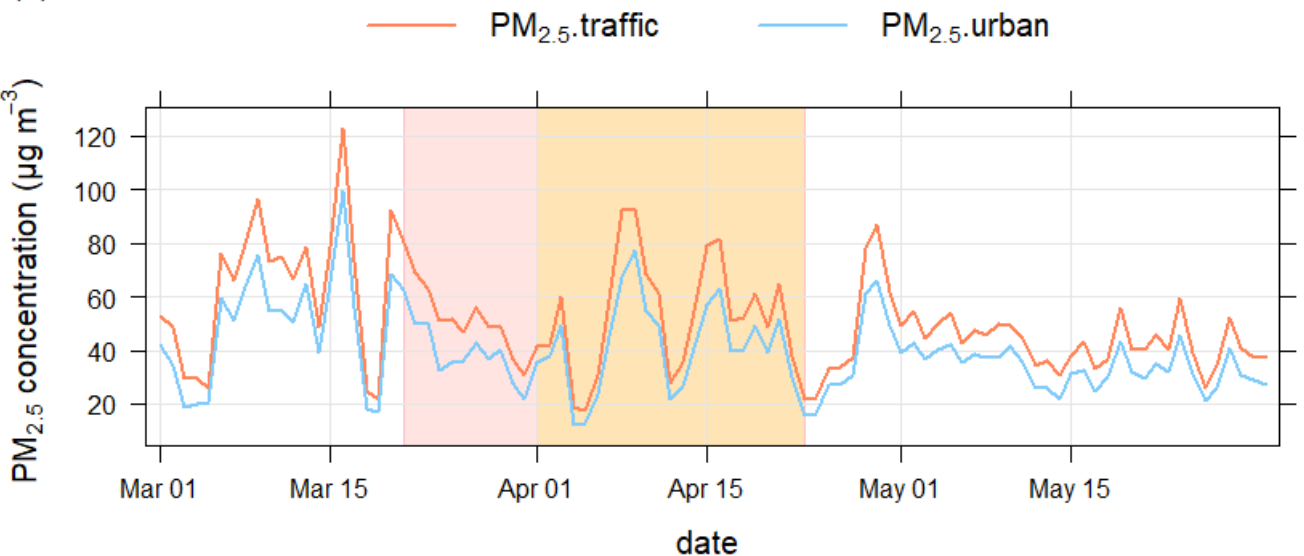

(b)

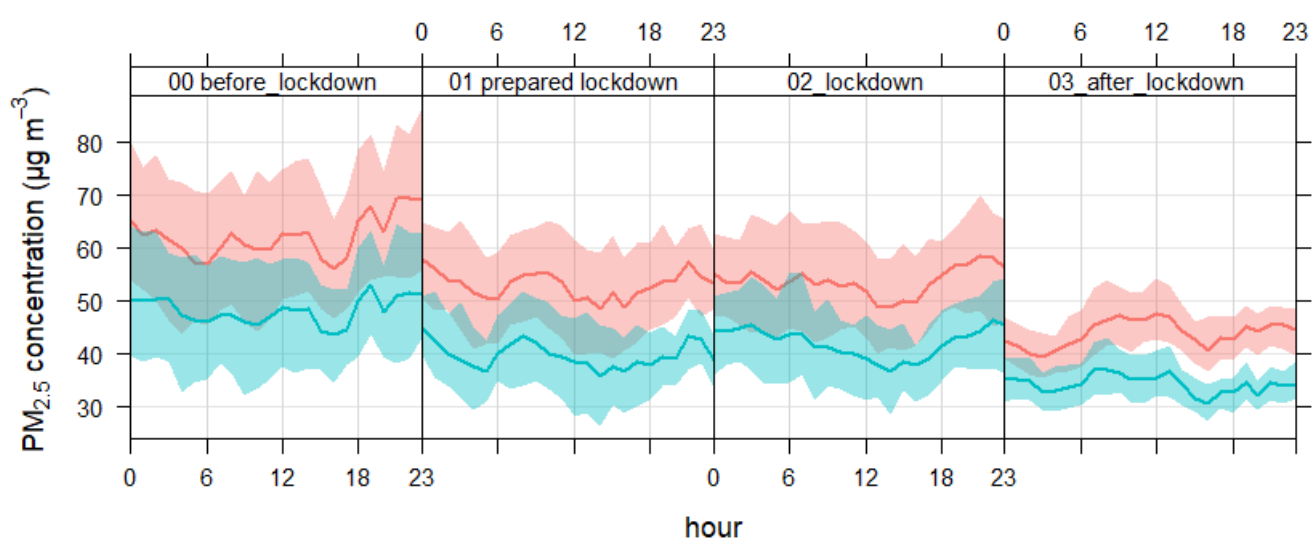

Fig. 2. (a) Daily concentrations of $P M_{2.5}$ during pre-, soft, hard, post social distancing periods in 2020: Pink shade denotes the soft social distancing period. Orange shade denotes the hard social distancing one. (b) Diurnal variations of $\mathrm{PM}_{2.5}$ concentrations.

levels at the roadside sites and strong impacts of weather on the dispersion, dilution, and elevation of fine particles at the urban scale. Explanation of these complex atmospheric processes of $\mathrm{PM}_{2.5}$ is out of the scope of this research.

\subsubsection{CO concentrations}

Fig. 3(a) shows large variations of daily $\mathrm{CO}$ concentrations. Its concentrations at urban stations fluctuated from approximately 400 to $1500 \mu \mathrm{g} \mathrm{m}^{-3}$, while those levels at roadside stations varied from approximately 500 to $2500 \mu \mathrm{g} \mathrm{m}^{-3}$, with the highest peaks happening in mid-March. The detailed statistics and Cls in 2019 and 2020 by each period are provided in Table S2. CO concentrations in this study are in agreement with the previous field measurements by Sakamoto et al. (2018) and Hien et al. (2002) who reported the annual levels of CO in Hanoi were around $1.3 \mathrm{ppm}\left(\sim 1.5 \mathrm{mg} \mathrm{m}^{-3}\right)$. Concentrations of $\mathrm{CO}$ during soft and hard social distancing periods decreased by $41 \%, 29 \%$ at urban sites, and $28 \%$ during both periods at traffic sites.

The correlation coefficients $(r)$ between $\mathrm{CO}$ levels from nine stations in the investigated periods were shown in Fig. S2(b). These $r$ values were in the range of $0.34-0.80$ which were lower than those for $\mathrm{PM}_{2.5}$, demonstrating that $\mathrm{CO}$ was more predominantly affected by local sources than $\mathrm{PM}_{2.5}$.

The observed CO concentrations at traffic sites were double those at urban sites in median (2.2, 1.8, 2.4 times in soft, hard, and after the social distancing, respectively) (Fig. 3(a)). In addition, the diurnal pattern (Fig. 3(b)) shows two distinct peaks coinciding with the traffic rush hours in Hanoi. At traffic peak hours, CO concentrations were approximately double those in the midnight 
(a)

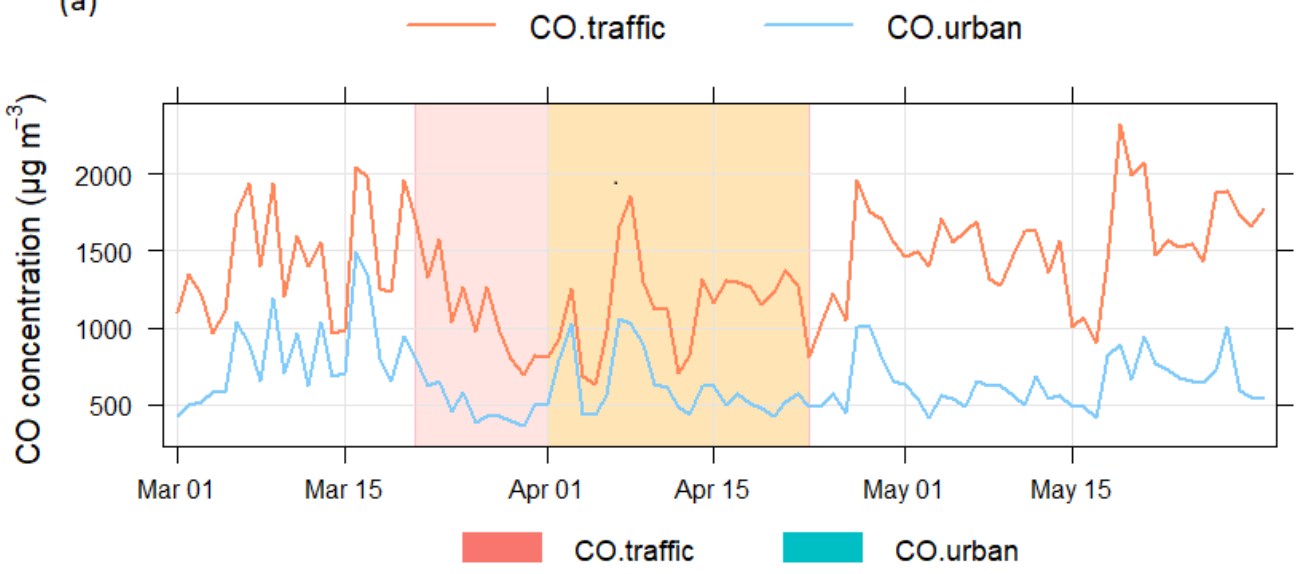

(b)

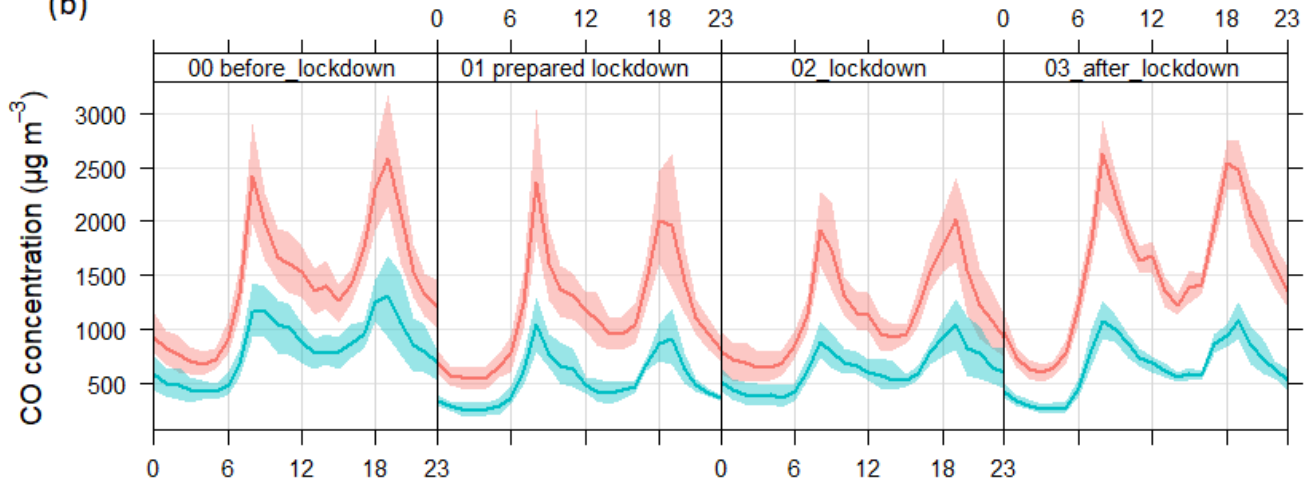

Fig. 3. (a) Daily concentrations of CO during pre-, soft, hard, post social distancing periods in 2020. Pink shade denotes the soft social distancing period. Orange shade denotes the hard social distancing one. (b) Diurnal variations of $\mathrm{CO}$ concentrations.

and midday concentrations. It indicated a stringent relation of $\mathrm{CO}$ concentrations with road traffic emissions. In addition, the diurnal pattern (Fig. 3(b)) shows two distinct peaks coinciding with the traffic rush hours in Hanoi. The effects of traffic emissions on both $\mathrm{CO}$ trend and concentrations are much clearer than on $\mathrm{PM}_{2.5}$.

\subsection{Impact of Meteorological Factors on $\mathrm{PM}_{2.5}$ Concentrations}

The following section illustrates the impact of important meteorological factors (wind speed, wind direction) and long-range transport on $\mathrm{PM}_{2.5}$. The information on meteorological conditions during the study period is provided in detail in Section S1 (Supplementary Material).

\subsubsection{Impact of wind speed and direction}

Wind speed plays a key role in the dispersion of air pollutants as demonstrated in previous studies (Hien et al., 2002; Ly et al., 2018., 2020). Fig. 4(a) shows most episodes of high PM2.5 concentrations associated with the low wind speed $\left(v<2.05 \mathrm{~m} \mathrm{~s}^{-1}\right)$. The windrose profile of $\mathrm{PM}_{2.5}$ concentrations in Fig. $4(\mathrm{~b})$ also confirmed such association. Low wind speed may associate with circle wind, and the measured wind direction is more affected by nearby terrain. At the high level of wind speed $\left(v>5 \mathrm{~m} \mathrm{~s}^{-1}\right)$, concentrations of $\mathrm{PM}_{2.5}$ were higher when the wind came from the eastern and southeastern directions (Fig. 4(b)), suggesting the impact of the sources of fine particles outside Hanoi city.

\subsubsection{Impact of air mass trajectories}

Fig. 5 illustrates the 6-hour average concentrations of $\mathrm{PM}_{2.5}$ and backward air mass trajectory clusters in 2020. Those clusters include C1: originated from the northeast, passing ocean before reaching Vietnam (26.0\%); C2: originated from north, northeast, passing land before reaching 


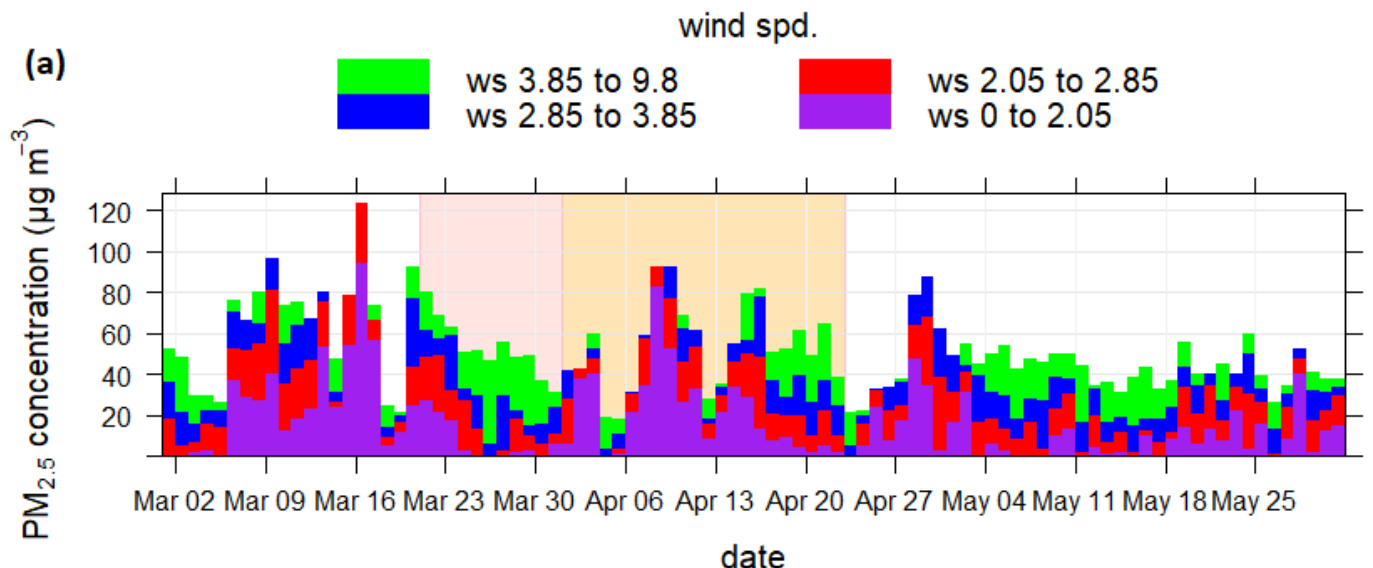

(b)

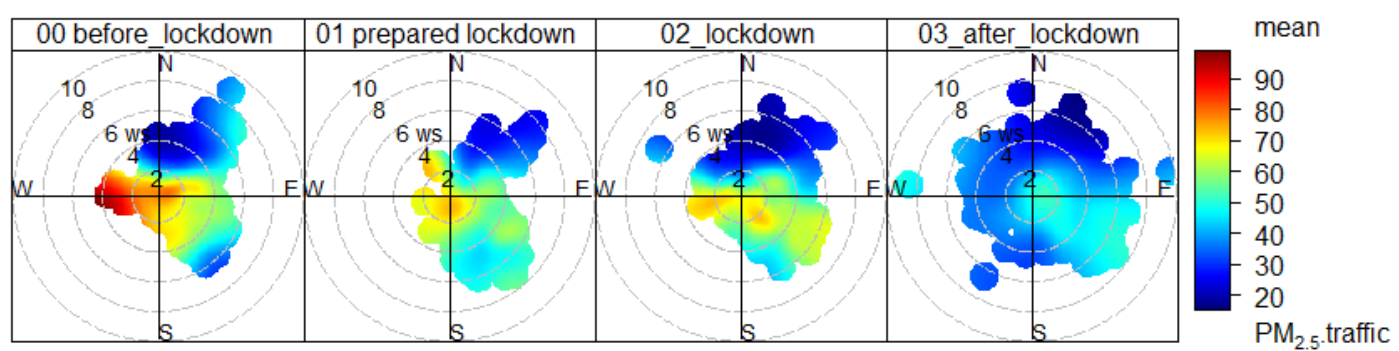

Fig. 4. Effects of wind speed on $\mathrm{PM}_{2.5}$ concentrations: (a) $\mathrm{PM}_{2.5}$ concentrations by wind speed; (b) Heat map of $\mathrm{PM}_{2.5}$ concentrations in relation to wind rose at traffic site.

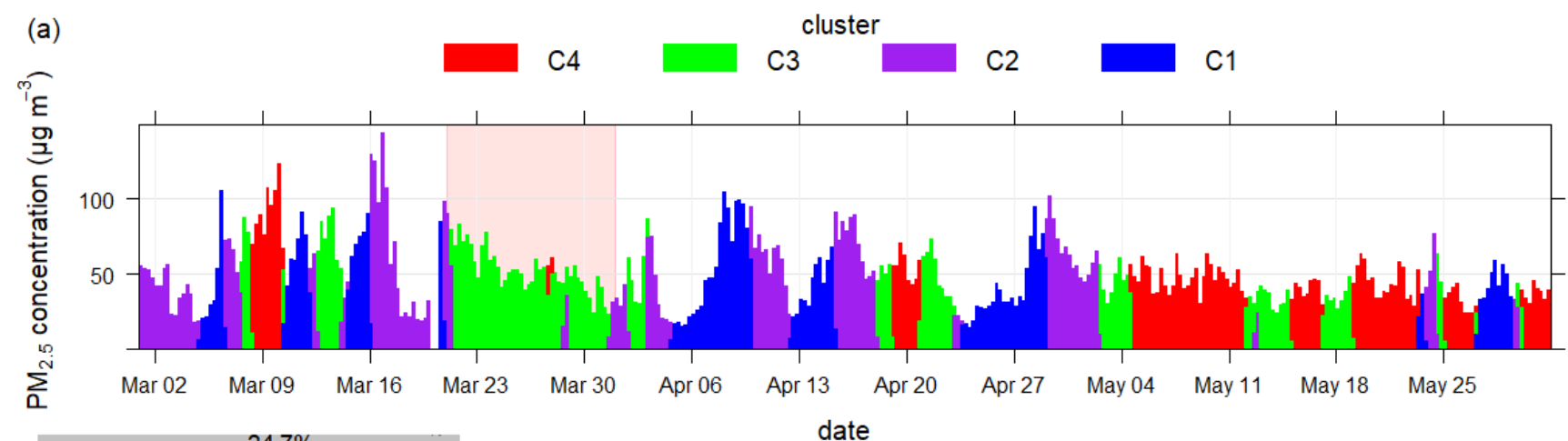

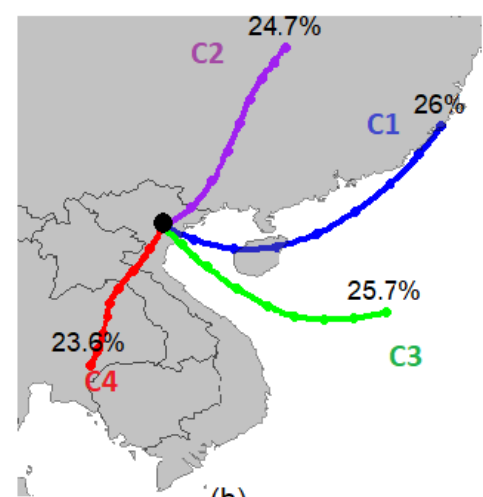

(b) contribution weighted by mean

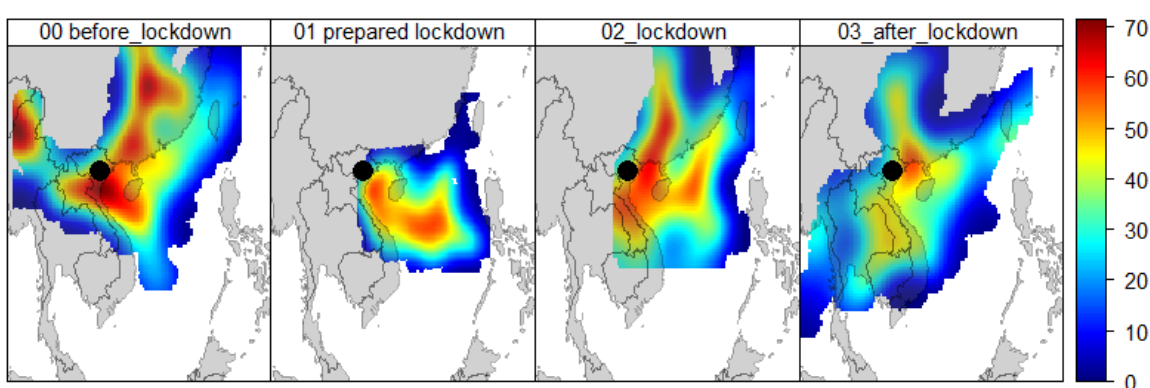

(c)

Fig. 5. Effects of backward air mass trajectories: (a) $\mathrm{PM}_{2.5}$ concentrations in relation to air mass trajectory clusters in 2020; (b) Air mass trajectory clusters in March-May 2020; (c) CWT in the pre-, during, and post social distancing periods. 
Vietnam (24.7\%); C3: Originated from the southeast (25.7\%); C4: Originated from the southwest (23.6\%). Accordingly, Hien et al. (2004) demonstrated that the different contributions of longrange transport and secondary formation on $\mathrm{PM}_{2.5}$ concentrations associate with different trajectory clusters. In short, the contributed percentage of long-range transport on $\mathrm{PM}_{2.5}$ was in the order of $\mathrm{C} 2>(\mathrm{C} 1, \mathrm{C} 3)>\mathrm{C} 4$. The contribution of secondary formation was highest with $(\mathrm{C} 1$, C3). Fig. 5(a) shows that all four clusters came to Hanoi quite evenly before the social distancing (pre-social distancing) period. During the soft social distancing period, the main air mass trajectory cluster was C3, from the southeast, then during the hard social distancing period, the C2 from north-northeast, land originated trajectory got the largest shared. Fig. 5(a) also shows the relationship of the backward trajectory with the highest $\mathrm{PM}_{2.5}$ events during those periods. The second event was related to the trajectory $\mathrm{C} 3$ from the southeast. The third major event of $\mathrm{PM}_{2.5}$ during the hard social distancing period relates to the first half of $\mathrm{C} 2$ from the mainland, northnortheast, and then $\mathrm{C} 1$ northeast from the sea. In the post-social distancing, the southeast (C4) trajectory cluster got the largest share in May. It corresponded with moderately low $\mathrm{PM}_{2.5}$ concentrations in May, notwithstanding its relation to a higher level of $\mathrm{PM}_{2.5}$ in April and the highest in March. The reason might be the biomass burning events during spring in the southeast area along the trajectory.

The CWT map (Fig. 5(c)) also shows a wide area of potential sources from north, northeast, southeast, and a small portion from the west to Hanoi in the pre-social distancing. During the social distancing, the potential source areas were mainly from the northeast to the south. In the post-social distancing, potential sources were enlarged to the southwest than those during the social distancing.

\subsection{Weather Normalized $\mathrm{PM}_{2.5}$ and CO Concentrations in Pre-, during, and Post-social Distancing}

\subsubsection{Weather normalized $\mathrm{PM}_{2.5}$ concentrations}

As presented in Section 3.1.1, during the pre-social distancing, urban and traffic sites had average $\mathrm{PM}_{2.5}$ concentrations of 48 and $62 \mu \mathrm{g} \mathrm{m}^{-3}$, respectively. As Hanoi observed noticeable precipitation and strong wind at the beginning of March, $\mathrm{PM}_{2.5}$ concentrations remained low, the minimum approximately 20-30 $\mathrm{g} \mathrm{m} \mathrm{m}^{-3}$. Wind speed decreased shortly afterward, leading to a rise in $\mathrm{PM}_{2.5}$ concentrations with a daily peak of $123 \mu \mathrm{g} \mathrm{m}^{-3}$. Observed concentrations of $\mathrm{PM}_{2.5}$ dropped in the social distancing period and even further after that.

To understand the influence of meteorological factors, we conducted weather normalization to estimate the hourly weather normalized $\mathrm{PM}_{2.5}$ concentrations as shown in Fig. 6.

Table S3 and Fig. S2(a) provide the performance metrics of our RF models. After normalizing the effects of meteorological factors, the variability of $\mathrm{PM}_{2.5}$ decreased largely compared to the original observed data. The corresponding weather normalized concentrations were 48 and $64 \mu \mathrm{g} \mathrm{m}^{-3}$ in the pre-social distancing. The decreases under the period of soft social distancing were recalculated to be $8 \%, 7 \%$ for urban and traffic stations. Afterward, weather normalized concentrations during hard social distancing decreased by $10 \%$ and $9 \%$ at urban and transportation stations.

Those reductions after de-weathering were quite less than the observed concentrations of $\mathrm{PM}_{2.5}$ (14-18\%), indicating the favored weather contributes significantly to the reductions of fine particles during soft and hard social distancing. Interestingly, in the post-social distancing, a further reduction of weather normalized $\mathrm{PM}_{2.5}$ concentrations were $17 \%$ and $21 \%$ at urban and traffic sites, respectively. Several reasons could be explained for those drops, especially the seasonality of primary, secondary, and long-range transport sources of aerosols. We note that summertime began in the post-social distancing period. Firstly, though the contribution of road traffic emission rose again in the post-social distancing period, other main primary sources of $\mathrm{PM}_{2.5}$ such as residential or agricultural emissions may continue to decrease. As discuss above biomass burning in the region (Thailand, Laos, Cambodia, Myanmar, Vietnam) occurs more frequently in spring (March-April) rather than in May when the social distancing ends (Bukowiecki et al., 2019; Sirimongkonlertkun, 2018). In another study, Vu et al. (2019) showed primary emissions of $\mathrm{PM}_{2.5}$ from the residential sector in Beijing decreased significantly during summertime during 2013-2017. The second reason could be the decrease in secondary aerosols. 

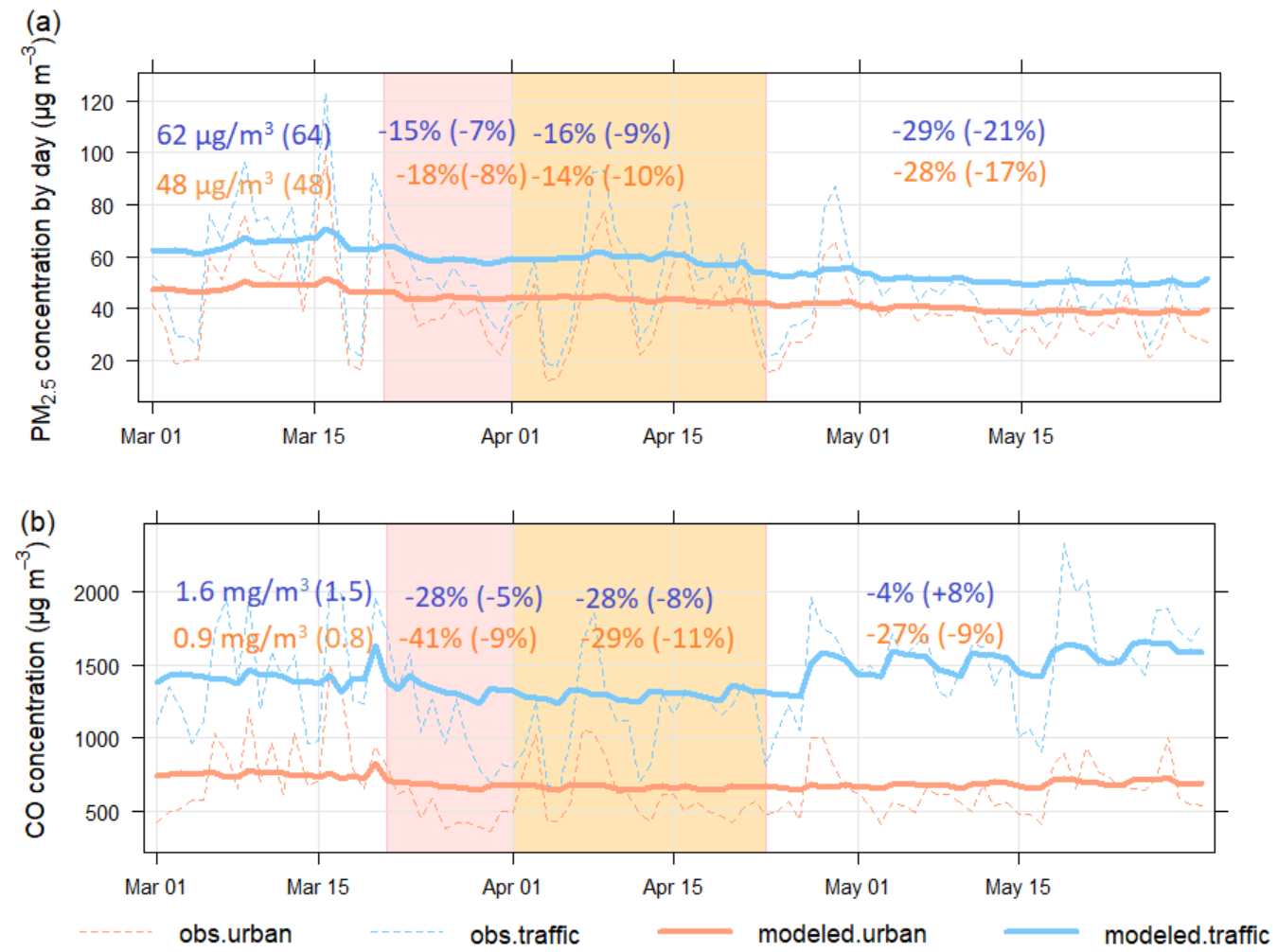

Fig. 6. Hourly concentration of weather normalized: (a) $\mathrm{PM}_{2.5}$, (b) $\mathrm{CO}$. The blue text represents the number at traffic sites, the orange text represents the number at urban sites.

Because of the higher mixing layer height in summer, secondary aerosols precursors such as $\mathrm{SO}_{2}$ and $\mathrm{NO}_{x}$ were more elevated, hence reducing their concentrations. A lower concentration of secondary aerosols in summer could lead to a smaller amount of secondary aerosols formed. In addition, extremely hot temperatures and lower humidity in summer could reduce concentrations of secondary aerosols. Since the temperature in the period of the post-social distancing (at $28^{\circ} \mathrm{C}$ ) was higher than in previous periods $\left(22-24^{\circ} \mathrm{C}\right)$, the secondary particles $\left(\mathrm{NH}_{4} \mathrm{NO}_{3}\right)$ have been volatilized partially, and the formation rate was slower as relative humidity was also low ( $<80 \%)$ (Dawson et al., 2007; Stelson and Seinfeld, 1982). Although we included the temperature and relative humidity as input variables in our random forest model, however, chemistry in secondary particle formation and sinks in Hanoi are very complex. Therefore, it requires a chemical transport model to investigate that since the random forest model by itself can hardly explain these phenomena. The third reason for the reduction of $\mathrm{PM}_{2.5}$ in the post-social distancing period could be the less contribution of regional transport of $\mathrm{PM}_{2.5}$ in summer. The transboundary of $\mathrm{PM}_{2.5}$ to Hanoi in the winter and spring have been highlighted significantly in the research of Hien et al. (2011), Ly et al. (2021). In our model, several air mass clusters only represent the origins of air masses but did not account for the contribution of individual air masses to $\mathrm{PM}_{2.5}$ concentrations quantitatively (Shi et al., 2021). Similar trends of weather normalization $\mathrm{PM}_{2.5}$ reduction toward summer were also found in 2019 as shown in Table S2. The reductions of PM2.5 in Hanoi in summer have been demonstrated in previous research (Cohen et al., 2011, Ly et al., 2018).

Strong impacts of meteorology, long-range transport, and atmospheric chemistry that contribute to the level of $\mathrm{PM}_{2.5}$ during COVID-19's lockdown period also be agreed upon by other studies. Those studies in the region also elucidated the unexpected pollution events that occurred during the lockdown time. Using a similar de-weather technique, Shi et al. (2021) observed an increase of $\mathrm{PM}_{2.5}$ in Bejing after the lockdown began. The unfavorable weather (high relative humidity, low wind speed, and boundary layer height) in Beijing-Hebei-Tianjin promotes the increase of heterogeneous aerosol chemistry (Chen et al., 2020). Long-range transport plays a crucial role in enhancing the fasting of the particular nitrate formation, the main factor contributing to the high atmospheric particle concentration in Shanghai (Chang et al., 2020). Otherwise, in Thailand, 
Dejchanchaiwong and Tekasakul (2021) explained the increase of $\mathrm{PM}_{2.5}$ under business areas in the lockdown period by identifying sources via calculating the ratio of organic carbon and elemental carbon (OC/EC) and backward trajectory simulation. The finding shows that the significant effects of local aerosol transport from open biomass burning in Thailand, Myanmar, Cambodia, Laos, and Vietnam affected the $\mathrm{PM}_{2.5}$ increase in Bangkok. Effectively controlling $\mathrm{PM}_{2.5}$ in any place in the region may require the co-effort from the neighborhood.

\subsubsection{Weather normalized CO concentrations}

The trend of daily concentrations of $\mathrm{CO}$ after de-weathering is shown in Fig. 6(b). Similar to $\mathrm{PM}_{2.5}$, re-examining the weather normalization shows smaller changes in CO levels than those observed concentrations at both two stations. Such reduction amounts were converted to $9 \%$ (soft social distancing), 11\% (hard social distancing), and 9\% (post-social distancing) at urban sites. It gradually decreased by $5 \%, 8 \%$ in the soft and hard social distancing, and then reverse the increase in the post-social distancing (8\%) at the traffic sites. It noted that the increasing trends of $\mathrm{CO}$ levels in the post-social distancing period were in contradiction with those for $\mathrm{PM}_{2.5}$. Those results point out much strong impact of road traffic emissions on CO levels, especially in traffic areas. The large contribution of transportation on $\mathrm{CO}$ emission has been proved in previous research (Duc and Duy, 2018). In addition, CO is a primary pollutant, therefore, its concentration is not heavily affected by secondary formation as $\mathrm{PM}_{2.5}$. Moreover, previous studies pointed the seasonal impacts due to emission changes have less impact on $C O$ than $\mathrm{PM}_{2.5}$ (Sakamoto et al., 2018).

In the post-social distancing period, the de-weathered CO level at traffic sites was $16 \%$ higher than those in the social distancing period, whereas there was little increase (2\%) at urban sites. It suggested that the main sources of $\mathrm{CO}$ at roadside sites were from traffic emissions, while sources of $\mathrm{CO}$ at urban background sites were not only from the road traffic emissions but also come from other sources in Hanoi such as residential (i.e., cooking) and industrial sectors and power plants as well (Amnuaylojaroen et al., 2014; Ellegård, 1997).

Other research in the region also presented a decrease in CO levels in Asian urban areas during the lockdown period in 2020, such as $22.7 \%$ in Wuhan-China (Lian et al., 2020), 16\% in Bangalore, 25\% in Chennai, 29\% in Kolkata and Delhi, 46\% in Mumbai - India (Jain and Sharma, 2020), 40.5\%47.5\% in Petaling Jaya-Malaysia (Mohd Nadzir et al., 2020), 1\%-27\% in several places-Malaysia (Suhaimi et al., 2020). Since CO is mainly derived from anthropogenic sources such as fuel combustion and automobile exhaust emissions (incomplete combustion process) (Kumar et al., 2013), the traffic stagnation highly influenced CO levels while governmental responses to COVID19 were implemented.

\subsection{Changes in Primary Emissions from Road Traffic and Coal-fired Plants}

Traffic emissions and coal-fired plants are two important sources of air pollutants, which have been received much attention from the public, researchers, and policy decision-makers. However, there is very limited information on the emission inventory of these sources in Hanoi. In this section, we investigated changes in primary emissions from these sources and possible effects among these changes on the ambient concentrations in pre/during/post social distancing periods.

\subsubsection{Potential effects of the changing of electricity production on pollutants' concentrations}

Coal-based electricity production in Vietnam has increased significantly from 11.9 billion kWh in 2008 (Vietnam National Energy Efficiency Programme, 2011) to nearly tenfold at 119.1 billion kWh in 2019 (Vietnam National Load Dispatch Center, 2020). During that period, the number of coal-fired power plants has increased from six plants with a total generation capacity of $1.5 \mathrm{GW}$ to 29 plants of around $20 \mathrm{GW}$ (V-LEEP, 2020). There are seven coal power plants at the northeast of Hanoi, and the nearest is the Pha Lai coal power plant in Hai Duong province (about $50 \mathrm{~km}$ away), and the farthest is the Na Duong coal power plant in Lang Son province (about $140 \mathrm{~km}$ away), and the remaining plants in the provinces are Thai Nguyen, Bac Giang, and the northern Quang Ninh provinces. Coal power plants emit $\mathrm{PM}, \mathrm{SO}_{2}$, and $\mathrm{NO}_{\mathrm{x}}$. The effects of coal power plants on PM in Hanoi are in two ways: the dispersion of PM; and the secondary aerosol formation, e.g., the reaction of $\mathrm{SO}_{2}$ and $\mathrm{NO}_{x}$ with $\mathrm{NH}_{3}$ in the atmosphere. Previous studies demonstrated that 


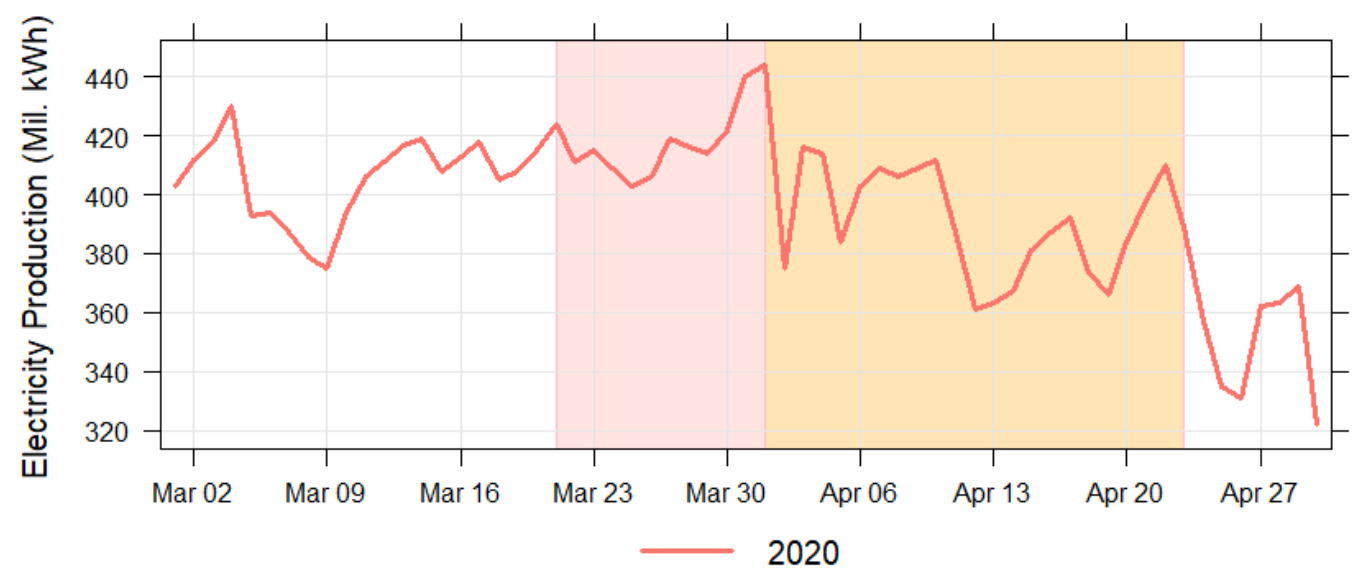

Fig. 7. Coal-fired electricity production time series during pre-, soft, hard, and post-social distancing in 2020.

coal-fired power plants in Vietnam contribute to $\mathrm{PM}_{2.5}$ concentrations in Hanoi at a magnitude of up to $3 \mu \mathrm{g} \mathrm{m}^{-3}$ of PM2.5 in Hanoi in 2011 (Koplitz et al., 2017). In other researches, the concentrations of average coal power plant (from both China and Vietnam) contributed $\mathrm{PM}_{2.5}$ during the period 2001-2008 was estimated at $9.3 \mu \mathrm{g} \mathrm{m}^{-3}$ (median of 6.7) out of $54 \mu \mathrm{g} \mathrm{m}^{-3}$ (median of 43), with local Vietnamese power plants contributed to $15 \%$ of extreme coal events (Cohen et al., 2010).

Fig. 7 shows that coal-fired electricity production increased by 25\% in March 2020 compared to the same month in 2019, while a 15\% increment was under observation between April 2019 and April 2020 (V-LEEP, 2020). The average production of coal-fired electricity was increased by $3 \%$ during the soft social distancing period but reduced by $3 \%$ under a hard social distancing condition. Those small variations implied that coal power plants might have little effect on the $\mathrm{PM}_{2.5}$ and $\mathrm{CO}$ trend. There was some evidence for a slight reduction in the industrial sector, through the labor market (Vietnam General Statistics Office, 2020), the electricity consumption may increase in the residential settings, compensating for the industrial decrease.

\subsubsection{Potential effects of the changing of transportation volume on pollutants' concentrations}

The transportation sector is the third-highest energy consumer in Vietnam, at approximately $22 \%$ of the total primary energy consumption (Dieu-Ha, 2010). This implies that transportation can be one of the main anthropogenic sources causing air pollution. $\mathrm{CO}$ emission of the transportation sector accounted for $85 \%$ of the air pollutants emission total in big cities, including Hanoi (Duc and Duy, 2018). The contribution of transportation to $\mathrm{PM}_{2.5}$ calculated by receptor modeling was 40\% from April 2001 to December 2009 (Cohen et al., 2010) and 10\% from January to February 2007 (Hai and Kim Oanh, 2013). In addition, 46\% of nanoparticles in Hanoi come from the transport sector (Nghiem et al., 2020). Therefore, the mobility trends during the COVID-19 social distancing period could strongly affect the air quality trend at this time, particularly $\mathrm{CO}$ and $\mathrm{PM}_{2.5}$ emission.

In this study, the mobility data were the counts of requests for directions in Vietnam from users using the Apple Maps app as presented in Fig. S4. According to Apple, the gaps will appear on the mobility trend profile if Apple does not have enough data to bring forward a confident estimation (Apple, 2020). Fortunately, there is no gap in the mobility trend profile of Vietnam from March 2020 to May 2020. As shown in Fig. S4, from January to May 2020, there are two troughs on the graph of mobility trends in Hanoi. The first trough corresponded to the Lunar New Year holiday period in January 2020, the second one corresponded to the period of hard social distancing in April 2020. Those facts showed that the mobility trend data were considerably reliable.

Fig. 8 presents the variation of community mobility in Hanoi by Google (Google, 2020). As shown in Fig. 8., during the social distancing period, most of the mobility demands declined acutely in contrast to the accelerating mobility in the residential area (an increment at approximately $30 \%$ ). The mobility demand in workplaces, transit stations, retails and recreation, parks, grocery, and pharmacies reduced gradually during the soft social distance and reached the maximum 


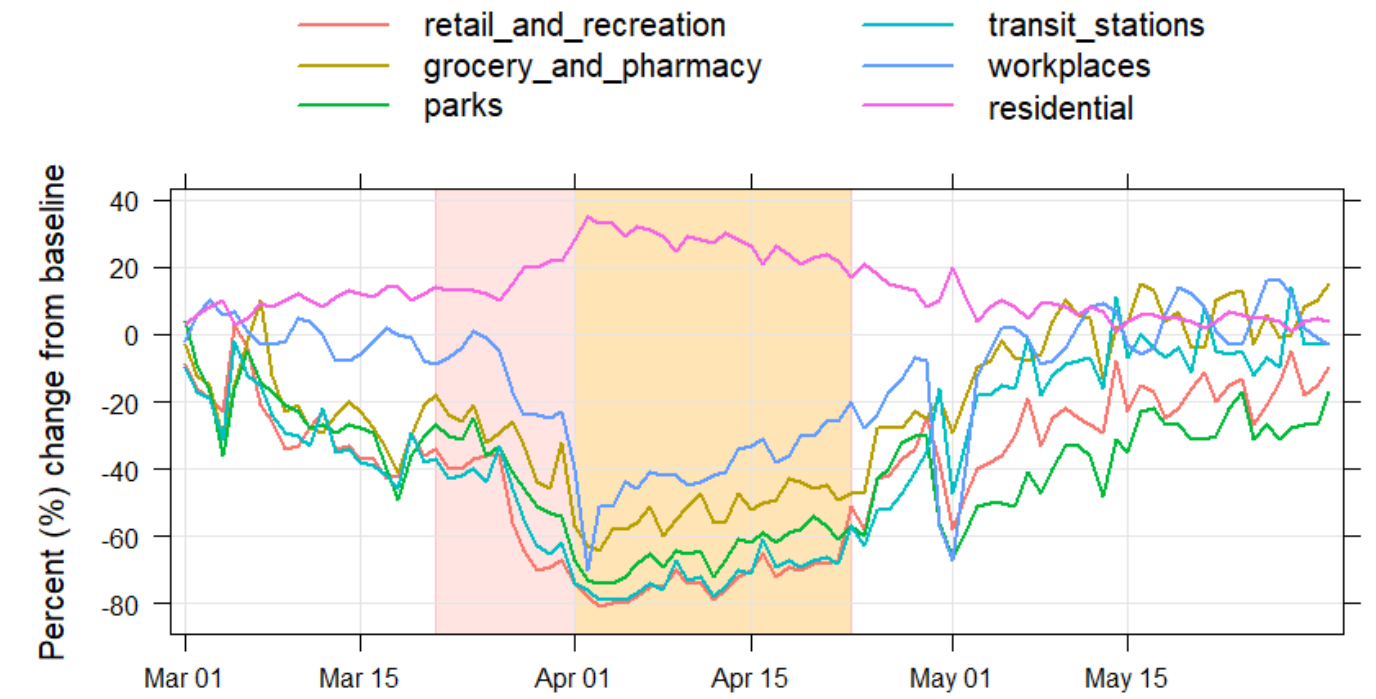

Fig. 8. Time series of community mobility in Hanoi from Google during pre-, soft, hard, and postthe social distancing in 2020.

reduction at the starting time of the hard social distance period. The maximum reduction was in the range of approximately $60-80 \%$. Reducing mobility demand in the social distancing period means reducing the traffic flow. Among the road vehicle fleets in Hanoi, motorcycles have the highest share of $92.6 \%$, then personal cars of $4.8 \%$, passenger cars of $0.5 \%$, trucks and buses of $2.1 \%$. All motorcycles and $93 \%$ of personal cars consume gasoline; up to $71 \%$ of passenger cars, $80 \%$ of trucks, and $99 \%$ of buses use diesel (Vietnamese Register, 2019). Section S2 in Supplementation Material provides the emission reductions estimated based on the transportation fleet reduction of motorcycles and buses and emission factors. During the hard social distance period, transportationrelated emission was estimated to reduce $60 \%$ and $49 \%$ of the total transportation-related emissions in the pre-social distancing period for $\mathrm{PM}_{2.5}$ and $\mathrm{CO}$, respectively. Those reductions were $37 \%$ and $33 \%$ in the soft social distancing period. Previously, Section 3.3.1 and 3.3.2 describe those reductions partly explain the reduction of weather normalized trend of $\mathrm{PM}_{2.5}$ and $\mathrm{CO}$.

Those findings showed the potential of reducing $\mathrm{PM}_{2.5}$ and $\mathrm{CO}$ concentrations by almost $10 \%$ when reducing the volume of traffic by $60 \%$ and restricting $100 \%$ bus operation with some uncertainty. In fact, this scenario cannot apply in the future because reducing transportation volume is difficult without increasing public transportation (e.g., buses). Nevertheless, other solutions for mitigating emissions from traditional bus fuels can be under consideration. A recent study convinced that the efficiency of changing bus fuel from diesel to CNG and LPG or standard tightening can reduce the emission from buses of $\mathrm{PM}_{10}$ (an equal value for $\mathrm{PM}_{2.5}$ can be reasonably assumed) by $99 \%$ (Nguyen et al., 2020). Strengthening the emission standard for buses from current EURO 2 to EURO 4 will also reduce $\mathrm{PM}_{2.5}$ by $83 \%$.

\section{CONCLUSIONS}

In conclusion, our results showed that both emission sources and meteorology play an important role in the reductions of $\mathrm{PM}_{2.5}$ and $\mathrm{CO}$ in Hanoi during the COVID-19 social distancing periods. After weather normalization, $\mathrm{PM}_{2.5}$ concentrations declined by only $7 \%-10 \%$ during the soft and hard social distancing period. A continuous drop of $\mathrm{PM}_{2.5}$ de-weathered concentrations after lifting social distancing indicated the level of $\mathrm{PM}_{2.5}$ in Hanoi is not only affected by traffic emission but strongly influenced by other sources, secondary aerosols, or long-range transport.

Weather normalized concentrations of $\mathrm{CO}$ declined by $5 \%-11 \%$ during the soft and hard social distancing periods. After those periods, $\mathrm{CO}$ concentrations increased strongly at traffic sites and moderately at urban sites, resulting in $16 \%$ and $2 \%$ increase, respectively, compared to the level observed during the hard social distancing periods. It confirms that traffic emissions have clear effects on $\mathrm{CO}$ levels than $\mathrm{PM}_{2.5}$ in Hanoi. 
The calculated reductions of traffic primary emissions during social distancing periods in Hanoi were $37-60 \%$ and $33-49 \%$ for $\mathrm{PM}_{2.5}$ and $\mathrm{CO}$, respectively. The results also showed the potential of reduction by almost $10 \%$ in ambient levels of $\mathrm{PM}_{2.5}$ and $\mathrm{CO}$ if the volume of transportation reduced by $60 \%$ and in the absence of bus operation.

\section{ACKNOWLEDGMENTS}

The authors sincerely acknowledged the Hanoi Department of Natural Resources and Environment for providing air pollution datasets and the USAID project "Collective Action for Clean Air" - Live \& Learn for facilitating network and collaboration.

\section{DISCLAIMER}

The authors declare that they have no known competing financial interests or personal relationships that could have appeared to influence the work reported in this paper.

\section{SUPPLEMENTARY MATERIAL}

Supplementary material for this article can be found in the online version at https://doi. org/10.4209/aaqr.210081

\section{REFERENCES}

Abdullah, S., Mansor, A.A., Napi, N.N.L.M., Mansor, W.N.W., Ahmed, A.N., Ismail, M., Ramly, Z.T.A. (2020). Air quality status during 2020 Malaysia movement control order (MCO) due to 2019 novel coronavirus (2019-nCoV) pandemic. Sci. Total Environ. 729, 139022. https://doi.org/ 10.1016/j.scitotenv.2020.139022

Amnuaylojaroen, T., Barth, M.C., Emmons, L.K., Carmichael, G.R., Kreasuwun, J., Prasitwattanaseree, S., Chantara, S. (2014). Effect of different emission inventories on modeled ozone and carbon monoxide in Southeast Asia. Atmos. Chem. Phys. 14, 12983-13012. https://doi.org/10.5194/a cp-14-12983-2014

Anh,K. (2020). Transport ministry loosens restrictions on public transport. Online Newspaper of the Government of The Socialist Republic of Vietnam. http://news.chinhphu.vn/Home/Transportministry-loosens-restrictions-on-public-transport/20204/39865.vgp (In Vietnamese) (accessed 24 August 2020).

Apple (2020). Mobility Trends Reports. https://covid19.apple.com/mobility (accessed 4 July 2021).

Bukowiecki, N., Steinbacher, M., Henne, S., Nguyen, N.A., Nguyen, X.A., Hoang, A.L., Nguyen, D.L., Duong, H.L., Engling, G., Wehrle, G., Gysel-Beer, M., Baltensperger, U. (2019). Effect of largescale biomass burning on aerosol optical properties at the GAW regional station Pha Din, Vietnam. Aerosol Air Qual. Res. 19, 1172-1187. https://doi.org/10.4209/aaqr.2018.11.0406

Carslaw, D.C., Taylor, P.J. (2009). Analysis of air pollution data at a mixed source location using boosted regression trees. Atmos. Environ. 43, 3563-3570. https://doi.org/10.1016/j.atmosen v.2009.04.001

Chang, Y., Huang, R.J., Ge, X., Huang, X., Hu, J., Duan, Y., Zou, Z., Liu, X., Lehmann, M.F. (2020). Puzzling haze events in China during the Coronavirus (COVID-19) shutdown. Geophys. Res. Lett. 47, e2020GL088533. https://doi.org/10.1029/2020gl088533

Chen, Y., Zhang, S., Peng, C., Shi, G., Tian, M., Huang, R.-J., Guo, D., Wang, H., Yao, X., Yang, F. (2020). Impact of the COVID-19 pandemic and control measures on air quality and aerosol light absorption in Southwestern China. Sci. Total Environ. 749, 141419. https://doi.org/10.1016/j.s citotenv.2020.141419

Cohen, D.D., Crawford, J., Stelcer, E., Bac, V.T. (2010). Characterisation and source apportionment of fine particulate sources at Hanoi from 2001 to 2008. Atmos. Environ. 44, 320-328. https://doi.org/10.1016/j.atmosenv.2009.10.037 
Dawson, J.P., Adams, P.J., Pandis, S.N. (2007). Atmospheric chemistry and physics sensitivity of $\mathrm{PM}_{2.5}$ to climate in the Eastern US: A modeling case study. Atmos. Chem. Phys. 7, 4295-4309. https://doi.org/10.5194/acp-7-4295-2007

Dejchanchaiwong, R., Tekasakul, P. (2021). Effects of Coronavirus induced city lockdown on PM2.5 and gaseous pollutant concentrations in Bangkok. Aerosol Air Qual. Res. 21, 200418. https://doi.org/10.4209/aaqr.200418

Dieu-Ha, N.K. (2010). Vietnam energy overview. Institute of Energy. http://ievn.com.vn/U serFile/Files/News/NLVN.pdf (accessed 3 July 2021).

Duc, K.N., Duy, V.N. (2018). Study on performance enhancement and emission reduction of used fuel-injected motorcycles using bi-fuel gasoline-LPG. Energy Sustainable Dev. 43, 60-67. https://doi.org/10.1016/j.esd.2017.12.005

Ellegård, A. (1997). Health effects of cooking air pollution among women using coal briquettes in hanoi. Environ. Technol. 18, 409-415. https://doi.org/10.1080/09593331808616554

ENVEA (2021). Hanoi (Vietnam): Cairsens PM micro-sensors help increase air quality monitoring coverage. https://www.envea.global/hanoi-vietnam-cairsens-pm-micro-sensors-help-increaseair-quality-monitoring-coverage/ (accessed 4 July 2021).

European Space Agency (2020). Air pollution remains low as Europeans stay at home. https://www.esa.int/Applications/Observing_the_Earth/Copernicus/Sentinel-5P/Air_pollutio n_remains_low_as_Europeans_stay_at_home (accessed 24 August 2020).

Google (2020). Community Mobility Reports. https://www.google.com/covid19/mobility/ (accessed 25 August 2021)

Grange, S.K., Carslaw, D.C., Lewis, A.C., Boleti, E., Hueglin, C. (2018). Random forest meteorological normalisation models for Swiss $\mathrm{PM}_{10}$ trend analysis. Atmos. Chem. Phys. 8, 6223-6239. https://doi.org/10.5194/acp-18-6223-2018

Ha, B.T.T., Ngoc Quang, L., Mirzoev, T., Tai, N.T., Thai, P.Q., Dinh, P.C. (2020). Combating the COVID-19 epidemic: Experiences from Vietnam. Int. J. Environ. Res. Public Health 17, 3125. https://doi.org/10.3390/ijerph17093125

Hai, C.D., Kim Oanh, N.T. (2013). Effects of local, regional meteorology and emission sources on mass and compositions of particulate matter in Hanoi. Atmos. Environ. 78, 105-112. https://doi.org/10.1016/j.atmosenv.2012.05.006

Hanoi DONRE (2018). Report of results of ambient air monitoring actitivies in Hanoi (in Vietnamese).

Hien, P.D., Bac, V.T., Tham, H.C., Nhan, D.D., Vinh, L.D. (2002). Influence of meteorological conditions on $\mathrm{PM}_{2.5}$ and $\mathrm{PM}_{2.5-10}$ concentrations during the monsoon season in Hanoi, Vietnam. Atmos. Environ. 36, 3473-3484. https://doi.org/10.1016/s1352-2310(02)00295-9

Hien, P.D., Loc, P.D., Dao, N.V. (2011). Air pollution episodes associated with East Asian winter monsoons. Sci. Total Environ. 409, 5063-5068. https://doi.org/10.1016/j.scitotenv.2011.08.049

Jain, S., Sharma, T. (2020). Social and travel lockdown impact considering Coronavirus disease (COVID-19) on air quality in megacities of India: Present benefits, future challenges and way forward. Aerosol Air Qual. Res. 20, 1222-1236. https://doi.org/10.4209/aaqr.2020.04.0171

Kim Oanh, N.T., Upadhyay, N., Zhuang, Y.H., Hao, Z.P., Murthy, D.V.S., Lestari, P., Villarin, J.T., Chengchua, K., Co, H.X., Dung, N.T. (2006). Particulate air pollution in six Asian cities: Spatial and temporal distributions, and associated sources. Atmos. Environ. 40, 3367-3380. https://doi.org/10.1016/j.atmosenv.2006.01.050

Koplitz, S.N., Jacob, D.J., Sulprizio, M.P., Myllyvirta, L., Reid, C. (2017). The burden of disease from rising coal-fired power plant emissions in Southeast Asia. Environ. Sci. Technol. 51, 1467-1476. https://doi.org/10.1021/acs.est.6b03731

Kumar, R., Naja, M., Pfister, G.G., Barth, M.C., Brasseur, G.P. (2013). Source attribution of carbon monoxide in India and surrounding regions during wintertime. J. Geophys. Res. 118, 19811995. https://doi.org/10.1002/jgrd.50134

Lian, X., Huang, J., Huang, R., Liu, C., Wang, L., Zhang, T. (2020). Impact of city lockdown on the air quality of COVID-19-hit of Wuhan city. Sci. Total Environ. 742, 140556. https://doi.org/10.1 016/j.scitotenv.2020.140556

Ly, B.T., Matsumi, Y., Nakayama, T., Sakamoto, Y., Kajii, Y., Nghiem, T.D. (2018). Characterizing $\mathrm{PM}_{2.5}$ in Hanoi with new high temporal resolution sensor. Aerosol Air Qual. Res. 18, 24872497. https://doi.org/10.4209/aaqr.2017.10.0435

Ly, B.T., Vu, T.A., Huong, P.T., Matsumi, Y., Kajii, Y., Sakamoto, Y. (2019). The effects of 
meteorological factors on $\mathrm{PM}_{2.5}$ and $\mathrm{O}_{3}$ an urban site in Hanoi. International Conference No.17 of Institute of Research on Science Physic and Architect and Construction, Russia. pp. 3-12.

Ly, B.T., Kajii, Y., Nguyen, T.Y.L., Shoji, K., Van, D.A., Do, T.N.N., Nghiem, T.D., Sakamoto, Y. (2020). Characteristics of roadside volatile organic compounds in an urban area dominated by gasoline vehicles, a case study in Hanoi. Chemosphere 254, 126749. https://doi.org/10.1016/j.chemos phere.2020.126749

Mohd Nadzir, M.S., Ooi, M.C.G., Alhasa, K.M., Bakar, M.A.A., Mohtar, A.A.A., Nor, M.F.F.M., Latif, M.T., Hamid, H.H.A., Ali, S.H.M., Ariff, N.M., Anuar, J., Ahamad, F., Azhari, A., Hanif, N.M., Subhi, M.A., Othman, M., Nor, M.Z.M. (2020). The impact of movement control order (MCO) during pandemic COVID-19 on local air quality in an urban area of Klang Valley, Malaysia. Aerosol Air Qual. Res. 20, 1237-1248. https://doi.org/10.4209/aaqr.2020.04.0163

Nghiem, T.D., Nguyen, T.T.T., Nguyen, T.T.H., Ly, B.T., Sekiguchi, K., Yamaguchi, R., Pham, C.T., Ho, Q.B., Nguyen, M.T., Duong, T.N. (2020). Chemical characterization and source apportionment of ambient nanoparticles: A case study in Hanoi, Vietnam. Environ. Scie. Pollut. Res. 27, 3066130672. https://doi.org/10.1007/s11356-020-09417-5

Nguyen, Y.L.T., Than, H.Y.T., L.H., M.B. (2020). Evaluation of the effectiveness of emission mitigation of environment protection solutions in Hanoi bus system Science Technology Conference XXII, University of Transportation and Communication, Hanoi, pp. 387-396. http://hnkh.utc.edu.vn/ky-yeu-hoi-nghi (in Vietnamese).

Nhu, V. (2020). Viet Nam to go into 15-day nationwide social distancing to curb COVID-19. http://news.chinhphu.vn/Home/Viet-Nam-to-go-into-15day-nationwide-social-distancing-tocurb-COVID19/20203/39472.vgp (accessed 23 July 2020).

Patel, K., Stevens, J. (2020). Airborne nitrogen dioxide plummets over China. NASA Earth Observatory. https://earthobservatory.nasa.gov/images/146362/airborne-nitrogen-dioxideplummets-over-china (accessed 24 July 2020).

Sakamoto, Y., Shoji, K., Bui, M.T., Phạm, T.H., Vu, T.A., Ly, B.T., Kajii, Y. (2018). Air quality study in Hanoi, Vietnam in 2015-2016 based on a one-year observation of $\mathrm{NO}_{\mathrm{x}}, \mathrm{O}_{3}, \mathrm{CO}$ and a one-week observation of VOCs. Atmos. Pollu. Res. 9, 544-551. https://doi.org/10.1016/j.apr.2017.12.001

Shi, Z., Song, C., Liu, B., Lu, G., Xu, J., Van Vu, T., Elliott, R.J.R., Li, W., Bloss, W.J., Harrison, R.M. (2021). Abrupt but smaller than expected changes in surface air quality attributable to COVID19 lockdowns. Sci. Adv. 7, eabd6696. https://doi.org/10.1126/sciadv.abd6696

Sirimongkonlertkun, N. (2018). Assessment of long-range transport contribution on haze episode in northern Thailand, Laos and Myanmar. IOP Conf. Ser.: Earth Environ. Sci. 151, 012017. https://doi.org/10.1088/1755-1315/151/1/012017

Stein, A.F., Draxler, R.R., Rolph, G.D., Stunder, B.J.B., Cohen, M.D., Ngan, F. (2015). NOAA's HYSPLIT atmospheric transport and dispersion modeling system. Bull. Am. Meteorol. Soc. 96, 2059-2077. https://doi.org/10.1175/bams-d-14-00110.1

Stelson, A.W., Seinfeld, J.H. (1982). Relative humidity and temperature dependence of the ammonium nitrate dissociation constant. Atmos. Environ. 16, 983-992. https://doi.org/10.10 16/0004-6981(82)90184-6

Suhaimi, N.F., Jalaludin, J., Latif, M.T. (2020). Demystifying a possible relationship between COVID-19, air quality and meteorological factors: Evidence from Kuala Lumpur, Malaysia. Aerosol Air Qual. Res. 20, 1520-1529. https://doi.org/10.4209/aaqr.2020.05.0218

Truc, V.T.Q., Kim Oanh, N.T. (2007). Roadside BTEX and other gaseous air pollutants in relation to emission sources. Atmos. Environ. 41, 7685-7697. https://doi.org/10.1016/j.atmosenv.200 7.06.003

Vietnam General Statistic Office (2020). Report on the impact of covid-19 on labor and employment of the third quarter of 2020. https://www.gso.gov.vn/en/data-and-statistics/20 20/10/report-on-the-impact-of-covid-19-on-labour-and-employment-of-the-third-quarter-of2020/ (accessed 2 October 2020)

Vietnam Low Emission Energy Program (V-LEEP) (2020). Assessment of Revised Power Development Plan 7 by using Production Cost Model with PLEXOS. http://vepg.vn/wp-content/uploads/202 0/11/USAID-V-LEEP-Report-on-Assessment-of-Revised-PDP-7-using-PLEXOS.pdf (accessed 2 December 2020).

Vietnam National Energy Efficiency Programme (2011). Vietnam energy statistics 2010.

Vietnam National Load Dispatch Center (2020). Vietnam power system and power market 
operation 2019.

Vietnamese Register (2019). Data of the vehicle fleet in Hanoi.

Vu, T.V., Shi, Z., Cheng, J., Zhang, Q., He, K., Wang, S., Harrison, R.M. (2019). Assessing the impact of clean air action on air quality trends in Beijing using a machine learning technique. Atmos. Chem. Phys. 19, 11303-11314. https://doi.org/10.5194/acp-19-11303-2019

Wang, P., Chen, K., Zhu, S., Wang, P., Zhang, H. (2020). Severe air pollution events not avoided by reduced anthropogenic activities during COVID-19 outbreak. Resour. Conserv. Recycl. 158, 104814. https://doi.org/10.1016/j.resconrec.2020.104814 